\title{
PELESTARIAN DAN PERLINDUNGAN TEMBAKAU DELI Sebuah Perspektif Historis
}

\section{Edi Sumarno}

Departemen Sejarah Fakultas Ilmu Budaya USU Medan, 20155

Corresponding author : semnastembakau@gmail.com

\begin{abstract}
ABSTARAK
Rencana pemberhentian/penghapusan budidaya Tembakau Deli di lingkungan PTPN 2 Tanjung Morawa sungguh sangat disayangkan. Betapa tidak? Rencana ini dikhawatirkan dapat mengakibatkan kepunahan Tembakau Deli, sebuah komoditas khas yang tiada duanya di muka bumi, yang hanya dapat diproduksi dan menghasilkan kualitas terbaik di lahan-lahan "istimewa" anugerah Tuhan, yakni di wilayah antara Sungai Wampu dan Sungai Ular. Keistimewaan Tembakau Deli ini juga didukung oleh sistem budidaya, mulai dari penyiapan lahan hingga pengolahan pasca panen, yang khas dan hanya ada di Sumatera Utara. Di samping kekhasan itu, Tembakau Deli juga memiliki nilai historis yang tinggi bagi Indonesia, khususnya Sumatera Utara. Tembakau Deli adalah "pemicu" perkembangan industri perkebunan di Provinsi Sumatera Utara, dan juga provinsi lain di Indonesia. Tidak terlalu berlebihan pula jika dikatakan bahwa Tembakau Deli adalah "pemicu" dari perkembangan Provinsi Sumatera Utara. Sumatera Utara pasti tidak akan seperti saat ini, jika tidak ada Tembakau Deli.
\end{abstract}

Keyword : tembakau Deli, perkebunan, kota Medan,

\section{PENDAHULUAN}

Tulisan sederhana ini akan membahas aspek historis dari Tembakau Deli, sebagai komoditas yang berperan penting dalam perkembangan Indonesia, khususnya Sumatera Utara. Untuk itu, tulisan ini akan membahas Tembakau Deli sebelum ekspansi perkebunan, kemunculan dan perkembangan perkebunan Tembakau Deli dari masa kolonial hingga saat ini, serta perannya sebagai pemicu perkembangan industri perkebunan dan Provinsi Sumatera Utara. Uraian ini dimaksudkan sebagai bahan pertimbangan untuk pelestarian dan perlindungannya sesuai dengan Undang-Undang Republik Indonesia Nomor 11 Tahun 2010 Tentang Cagar Budaya. 


\section{Tembakau Deli Sebelum Ekspansi Onderneming}

Sumatera Utara $^{1}$ (baca: Sumatera Timur ${ }^{2}$ ) sebelum adanya ekspansi ekonomi onderneming, belum begitu dikenal. Wilayah ini baru dianeksasi Belanda di tahun $1858,{ }^{3}$ tetapi baru mulai berkembang sejak awal penanaman Tembakau Deli di tahun 1860 -an. ${ }^{4}$ Saat itu, wilayahnya masih dipenuhi hutan belukar, dan penduduknya juga masih terbilang jarang. Pusat-pusat kekuasaan pribumi umumnya berada di sungai atau muara yang sekaligus sebagai pusat perdagangan dan kota pelabuhan tradisional. ${ }^{5}$ Infrastruktur penghubung antara wilayah pesisir dan pedalaman juga masih belum memadai, dan masih mengandalkan sungai. Meskipun denyut ekonomi pasar sudah menyentuh wilayah ini sejak lama, namun dapat dikatakan ekonomi wilayah ini belum begitu berkembang, sebagian karena masih mengandalkan pertanian rakyat, dan sebagian lagi karena seringkali dilanda konflik antara sesama kekuasaan tradisional setempat.

Sebelum tahun 1860-an, istilah Tembakau Deli tidak pernah dikenal. Masyarakat setempat dan laporan-laporan asing juga tidak menyebut nama Tembakau Deli, tetapi cukup tembakau saja. Istilah ini mulai digunakan setelah tahun 1860-an, saat mana tembakau yang berasal dari Deli mulai digemari karena kualitasnya yang sangat baik dan bernilai tinggi. Sejak itu kemudian dikenallah istilah Deli Tabak, atau Tembakau Deli.

Tidak banyak informasi yang diperoleh tentang budidaya tembakau oleh penduduk setempat sebelum terjadinya ekspansi ekonomi perkebunan sejak tahun 1860-an itu. Meski demikian, laporan Anderson ${ }^{6}$ tahun 1823 kiranya memberikan sedikit gambaran menarik tentang situasi pertanian, termasuk tembakau, di Sumatera Utara. Diinformasikan bahwa saat dia melakukan perjalanan di beberapa kawasan di Sumatera Timur, seperti Langkat, Deli,

1 Sumatera Utara, atau tepatnya Provinsi Sumatera Utara saat ini adalah gabungan wilayah eksKeresidenan Sumatera Timur, dan eks-Keresidenan Tapanuli masa kolonial.

2 Sumatera Timur adalah eks-Keresidenan pada masa kolonial yang terdiri dari Afdeling-afdeling Langkat, Deli en Serdang, Simeloengoen en Karo Landen, Asahan, dan Bengkalis dengan pusatnya Medan. Afdeling Bengkalis, sejak Masa Pemerintahan Militer Jepang kemudian dimasukkan ke dalam wilayah Riau.

${ }^{3}$ Tanggal 1 Februari 1858, lewat Traktat Siak, wilayah Sumatera Timur secara de jure dianggap tunduk dan masuk dalam kekuasaan Kolonial Belanda.

${ }^{4}$ Pelopor dari industri perkebunan Tembakau Deli adalah Jacobus Nienhuijs. Dia adalah orang Belanda pertama yang membuka perkebunan di Deli pada tahun 1863.

5 Edi Sumarno, "Mundurnya Kota Pelabuhan Tradisional di Sumatera Timur pada Periode Kolonial" dalam Historisme Edisi NO.22/Tahun XI/Agustus 2006, hlm. 2.

${ }^{6}$ John Anderson adalah seorang petualang yang ditugaskan oleh pemerintahan Inggeris di Semenanjung untuk meneliti kawasan Timur Sumatera guna melihat kemungkinan membuka hubungan ekonomi dan politik dengan kawasan itu tahun 1823. Hasil penelitian itu kemudian dibukukan dan diterbitlan dengan judul Mission to the East Coast of Sumatra in 1823. 
Serdang, dan Asahan, pertanian penduduk umumnya terutama adalah lada. Dapat dikatakan primadona pertanian rakyat saat itu adalah lada. Selain lada, penduduk setempat juga memproduksi kelapa (kopra), kopi, gambir, pinang, dan juga tembakau. Tentang tembakau, Anderson menyatakan bahwa penanamannya tidak dilakukan secara khusus, tetapi sebagai tanaman tumpang sari dari tanaman lada. Tembakau yang dihasilkan, sebagian dikonsumsi sendiri untuk rokok dan kebiasaan menyirih, dan sebagian lagi dijual untuk diekspor ke Penang. Untuk keperluan apa ekspor tembakau, tidak disebutkan dalam laporannya.

Selanjutnya, Anderson menginformasikan:

"Tembakau ditanam oleh orang-orang Melayu dan orang-orang Batak. Mereka menaburkan bibit-bibit di persemaian kecil, dan kemudian mencabut dan menanamnya kembali sesudah dua puluh hari dalam deretan kira-kira dua kubit. Dalam tempo empat bulan ia telah masak. Sesudah dua bulan pucuknya dipotong, yang memberikan kekuatan dan membuat daun-daunnya bertambah lebar. Apabila tanaman itu telah mempunyai tujuh helai daun, para penanam mulai memanen daundaun tembakau itu. Tandanya, daun itu mulai layu terkulai, dan berwarna kecoklatcoklatan. Dalam sekali panen para petani memetik satu atau dua helai daun, sesuai dengan saat daun-daun itu mendekati keadaan masak. Daun-daun itu mendekati keadaan masak. Daun-daun itu dibiarkan disinari matahari selama empat hari, dan kemudian dimasukkan ke dalam keranjang-keranjang kecil, tempat tembakau itu diekspor. Jika bibit-bibit perlu diawetkan, sudah tentu pucuk-pucuk tanaman itu tidak disentuh-sentuh". ${ }^{7}$

Setelah laporan Anderson, penulis tidak menemukan informasi tentang pertanian tembakau hingga tahun 1860-an. Tentang situasi ini, seorang controleur di Deli menginformasikan bahwa di Kesultanan Langkat, Deli, dan Serdang, tembakau juga masih dibudidayakan oleh penduduk setempat, tetapi yang masih menjadi primadona adalah lada. Gambaran controleur tersebut tentang pertanian tembakau oleh penduduk setempat menunjukkan pola yang belum berubah seperti apa yang diinformasikan oleh Anderson di tahun 1820-an. ${ }^{8}$

\section{PERKEMBANGAN TEMBAKAU DELI DI ERA KOLONIAL}

Ekspansi onderneming Tembakau Deli di Sumatera Timur dipelopori oleh seorang Belanda J. Nienhujs yang datang ke Deli atas ajakan Said Abdullah pada 1863. Dalam kunjungannya ke Deli, dia melihat bahwa komoditi tembakau merupakan tanaman yang hlm. 280 .

${ }^{7}$ John Anderson, Mission to the East Coast of Sumatra in 1823, New York: Oxford University, 1971,

8 J.A.M. van Cats Baron de Raet, "Vergelijking van de vroegeren Toestand van Deli, Serdang, en Langkat", dalam Tijdschrift voor Indische Taal, Land, en Volkenkunde van Bataviasch Genootschap, deel XII, 1887, hlm. 34-37. 
dibudidayakan oleh masyarakat setempat, walaupun masih dalam jumlah terlalu kecil untuk dijadikan barang ekspor. Dengan bantuan Said Abdullah yang mendapatkan kepercayaan dari Sultan Deli, Nienhujs berhasil mendapatkan konsesi tanah untuk membuka perkebunan tembakau di tanah Deli. Daerah konsesi untuk penanaman tembakau yang pertama letaknya di tepi Sungai Deli dengan luas 4.000 bau. ${ }^{9}$ Perjanjian konsesi diberikan selama 20 tahun. Selama 5 tahun pertama dia dibebaskan dari pembayaran pajak dan sesudah itu baru membayar 200 gulden setahun. ${ }^{10}$

Usaha penanaman tembakau yang dirintis oleh Nienhujs awalnya mengalami kerugian yang cukup besar. Padahal perusahaan yang membiayainya, yakni Pieter van den Arend telah mengeluarkan modal sebesar $f$ 5.000,-. Nienhujs belum mampu memenuhi ekspektasi dari Pieter van den Arend dan hanya 50 bal tembakau yang dikirim ke pelelangan di Rotterdam. ${ }^{11}$ Pada penanaman berikutnya, Nienhuijs mencoba melaksanakan sistem borongan dengan pembayaran di muka. Meskipun para pemborong menerima bayaran itu namun hasil panen para penanam tembakau subsisten itu tidak bisa memenuhi permintaan. ${ }^{12}$

Namun Nienhuijs tetap bersikukuh bahwa tanah Deli akan mendatangkan keuntungan yang besar. Kegagalannya dalam sistem borongan yang diterapkan dan adanya desakan dari pihak Pieter van den Arend, Nienhuijs kemudian membuka kebun percobaan di atas sebidang tanah yang disewanya seluas 75 ha di Tanjung Sepassai, dekat Titi Papan. Namun muncul masalah lainnya yakni kebutuhan akan tenaga kerja yang banyak. Penolakan petani pribumi memaksanya mengupah beberapa Haji Jawa dan pengikutnya dari Pulau Pinang untuk memborong penggarapan sekaligus mengawasi pekerjaan penanaman penduduk lokal yang masih setia. Dari kebun percobaan ini Nienhuijs menghasilkan 25 bal tembakau yang dihargai $f 0,48$ per setengah kilogramnya. ${ }^{13}$ Kegigihannya ini menunjukkan hasil ketika tembakau yang diekspor ke Rotterdam mendapatkan apresiasi yang tinggi.

Setelah kerja borongan para Haji Jawa berakhir tidak memuaskan, menjelang musim tanam 1865 Nienhuijs mendatangkan kuli Cina dari Pulau Pinang menyusul 88 kuli Cina dari

\footnotetext{
${ }^{9} 1 \mathrm{bau}=0,7 \mathrm{ha}$.

10 Thee Kian Wie, Plantation Agriculture and Export Growth an Economic History of East Sumatra 1863-1942. Jakarta: National of Institute of Economic and Social Research (LEKNAS - LIPI), 1977, hlm. 3.

11 Fatimah, "Pengaruh Sosial Ekonomis Perkebunan Tembakau Terhadap Masyarakat di Sumatera Timur" Tesis belum diterbitkan, Yogyakarta: Universitas Gadjah Mada, 1985, hlm. 28.

12 Mohammad Said, Koeli Kontrak Tempoe Doeloe: dengan Derita dan Kemarahannya, Medan: Waspada, 1977, hlm. 29.

${ }^{13}$ Karl J. Pelzer. Toean Keboen dan Petani: Politik Kolonial dan Perjuangan Agraria. Jakarta: Pustaka Sinar Harapan. 1985, hlm. 54.
} 
daratan Cina langsung. Para kuli Cina, sekalipun tidak mengetahui seluk beluk penanaman tembakau, pada akhir musim panen 1865 bisa menghasilkan 189 bal tembakau bermutu baik yang dihargai $f .2,51$,- per setengah kilogram. ${ }^{14}$ Tetapi usaha ini tetap dianggap gagal oleh Pieter van den Arend dan menghentikan kerjasama dengan Nienhuijs. Keadaan ini tidak membuat putus asa Nienhuijs. Ia kemudian mencari investor lainnya yang mau menanam modalnya di perkebunan tembakau di Deli. Ia berhasil mendapatkan dukungan G.C. Clemen dan P.W. Janssen, pedagang tembakau Amsterdam dengan modal \$ 10.000. Pada akhir Desember 1867, sepulangnya dari Negeri Belanda, ia berhasil mendapat konsesi tanah selama 99 tahun yang terletak antara Sungai Deli dan Sungai Percut memanjang sepanjang dari kampung Mabar hingga Deli Tua. Pada tahun 1868, biaya produksinya 30.000 gulden dan menghasilkan 67.000 gulden, tahun berikutnya ia memperoleh keuntungan 36.400 gulden dan 87.200 gulden. ${ }^{15}$ Nienhuijs dan para perintis lainnya, pada saat itu telah berhasil membuktikan bahwa tembakau yang dihasilkan di Deli merupakan produk yang sangat menguntungkan di pasar perdagangan Eropa dan menjadikan Deli sebagai penghasil pembungkus cerutu terbaik di dunia.

Sebagaimana diketahui ekspansi onderneming di Sumatera Timur dirintis oleh Nienhuijs yang mencoba menanam tembakau di Deli tahun 1863. Kendati awalnya kurang berhasil, tetapi sejak itu ekspansi kemudian berjalan dengan skala besar. Pada tahun 1869 Nienhuijs mendirikan Deli Maatschappij, perseroan terbatas pertama yang beroperasi di Hindia Belanda. ${ }^{16}$ Selanjutnya pada tahun 1871 didirikan Senembah Maatschappij dan pada tahun 1873 sudah terdapat 15 onderneming, 13 di Deli dan masing-masing 1 di Langkat dan Serdang. Pada tahun 1875 dan 1877, didirikan Arendsburg Tabak Mij. dan Deli Batavia Maatschappij. ${ }^{17}$ Angka ini terus bertambah, sehingga di tahun 1884 menjadi 86 onderneming, yakni 44 di Deli, 20 di Langkat, 9 di Serdang, dan 3 di Padang Bedagai. Ekspansi onderneming di beberapa daerah ini tentu saja menggunakan lahan yang tidak sedikit dan tersebar di beberapa daerah di Sumatera Timur. ${ }^{18}$ Berikut adalah data tentang jumlah onderneming tembakau yang beroperasi selama 40 tahun di Sumatera Timur, yakni dari tahun $1864-1904$.

\footnotetext{
${ }^{14}$ Fatimah, op. cit., hlm. 52.

15 Ann Laura Stoler, Kapitalisme dan Konfrontasi di Sabuk Perkebunan Sumatera (1870-1979), Yogyakarta: Karsa, 2005, hlm. 57-58.

16 Jan Breman, Menjinakkan Sang Kuli: Politik Kolonial, Tuan Kebun, dan Kuli di Sumatera Timur pada Awal Abad ke-20, Jakarta: Pustaka Utama Grafiti dan KITLV, 1997, hlm. 26.

${ }^{17}$ T. Volker, Van Oerbosch Tot Cultuurgebied: Een Schets van de Beteekenis van de Tabak, de Andere Cultures, en de Industrie ter Oostkust van Sumatra, Medan, De Deli Planters Vereeniging, 1918, hlm. 15.

${ }^{18}$ Edi Sumarno, op.cit., hlm. 2.
} 
Tabel 1. Jumlah Onderneming Tembakau di Sumatera Timur 1864-1904

\begin{tabular}{cccc}
\hline Tahun & Jumlah & Tahun & Jumlah \\
\hline 1864 & 1 & 1887 & 114 \\
1873 & 13 & 1888 & 141 \\
1874 & 23 & 1889 & 153 \\
1876 & 40 & 1891 & 169 \\
1881 & 67 & 1892 & 135 \\
1883 & 74 & 1893 & 124 \\
1884 & 76 & 1894 & 111 \\
1885 & 88 & 1900 & 139 \\
1886 & 104 & 1904 & 114
\end{tabular}

Sumber: Jan Breman, Menjinakkan Sang Kuli: Politik Kolonial, Tuan Kebun, dan Kuli di Sumatera Timur pada Awal Abad ke-20, Jakarta: Pustaka Utama Grafiti dan KITLV, 1997, hlm. 71.

Dari tabel di atas terlihat, adanya peningkatan jumlah onderneming Tembakau Deli di Sumatera Timur antara periode tahun 1864 hingga tahun 1891. Penurunan terjadi mulai tahun 1892, saat mana terjadi over produksi tembakau di pasar dunia, boikot atas praktik Poenale Sanctie, penerapan "Bea McKinley", dan tentunya penurunan harga tembakau. Sejak itu jumlahnya menurun, sempat naik di tahun 1900, tetapi setelahnya terus mengalami penurunan.

Tanda-tanda menurunnya budidaya Perkebunan Tembakau Deli mulai terlihat sejak tahun 1891, saat mana terjadi over produksi dengan bertambahnya kompetitor tembakau sejenis dari Afrika dan Amerika, serta trend penurunan harga tembakau yang menyertainya. Sejak itu, bahkan hingga kini, era keemasan Tembakau Deli berangsur surut. Pada periode kolonial, penurunan itu terjadi sejak awal tahun 1890-an, dan terus berlanjut. Sejak saat itu, onderneming Tembakau Deli hanya tersisa di Langkat dan Deli Serdang. Di awal tahun 1900an, sebagian onderneming tembakau tersebut beralih pula ke tanaman lain, terutama karet. Semakin turunnya harga tembakau di pasar dunia, berdampak pula pada berkurangnya jumlah onderneming Tembakau Deli. Puncak penurunan pada periode kolonial terjadi saat terjadinya Depresi Besar, biasa juga disebut Masa Maleise, sejak tahun 1930 yang berakibat pada 
penurunan harga komoditas, termasuk tembakau di pasar internasional. Berikut adalah tabel penciutan jumlah onderneming Tembakau Deli sejak tahun 1904 hingga tahun 1940.

Tabel 2. Penciutan Jumlah Onderneming Tembakau Deli, 1904 -1940

\begin{tabular}{cccc}
\hline Tahun & Jumlah & Tahun & Jumlah \\
\hline 1904 & 114 & 1931 & 67 \\
1912 & 97 & 1932 & 61 \\
1920 & 82 & 1934 & 45 \\
1928 & 72 & 1940 & 45
\end{tabular}

Sumber: Karl J. Pelzer, Toean Keboen dan Petani: Politik Kolonial dan Perjuangan Agraria Di Sumatera Timur, 1863-1947, Jakarta: Sinar Harapan, 1985, hlm. 73.

Tabel di atas menunjukkan, terjadi penciutan jumlah onderneming Tembakau Deli sejak 1904 - 1940. Pada periode 1904 - 1928, besar kemungkinan penciutan diakibatkan oleh penurunan harga, seiring pula dengan peralihan ke tanaman lain, terutama karet. Memang, sejak awal tahun 1920-an angka-angka menunjukkan bahwa nilai ekspor karet Sumatera Timur sudah melewati tembakau. Selanjutnya, penurunan terus terjadi akibat dampak Depresi Besar sejak tahun 1930. Menjelang akhir kekuasaan Belanda, jumlah onderneming Tembakau Deli di Sumatera Timur hanya tinggal 45 buah, bandingkan dengan masa puncaknya di tahun 1891 (lihat tabel 1) yang berjumlah 169 perkebunan.

\section{PERKEMBANGAN TEMBAKAU DELI DI MASSA PENDUDUKAN JEPANG HINGGA SEKARANG}

Pada masa pendudukan Jepang dapat dikatakan perkebunan kurang mendapat perhatian oleh penguasa. Hal ini karena Jepang fokus pada kebutuhan logistik perang, sehingga banyak kebun-kebun tembakau kurang mendapat perhatian. Bahkan, banyak lahanlahan tembakau yang diberikan kepada para pekerja dan penduduk lainnya untuk penanaman pangan guna kebutuhan logistik perang. Hal ini menyebabkan kerusakan pada sistem penggiliran lahan tembakau dan kerusakan tanah yang sebelumnya telah terawat dengan baik. Banyak lahan-lahan Tembakau Deli digunakan tidak hanya tanaman pangan seperti, padi, jagung, dan ubi tetap untuk tanaman industri lain yakni serat, kacang-kacangan, dan tanaman jarak. $^{19}$

\footnotetext{
${ }^{19}$ Karl J. Pelzer, op.cit., hlm. 153.
} 
Tidak hanya lahan yang mengalami pengurangan, jumlah produksi Tembakau Deli dapat dikatakan berada pada titik nadir. Pemerintah Jepang hanya memberikan wewenang pada perkebunan Deli Tua untuk menanam Tembakau Deli pada lahan kira-kira 100 ha. Produksi pada 1943 berjumlah $40.000 \mathrm{bal}$, tahun berikutnya mengalami penurunan yang sangat drastis hingga kira-kira 1.000 bal. Bahkan pada 1945 hingga 1946 tidak ada hasil dari produksi Tembakau Deli yang ditanam di perkebunan. ${ }^{20}$

Masa Jepang merupakan awal dari kerusakan sistem perkebunan Tembakau Deli dan penjarahan lahan serta sengketa agraria di Sumatera Utara. Hal ini berakibat pada semakin berkurang dan menciutnya lahan perkebunan Tembakau Deli. Penjarahan lahan-lahan perkebunan tembakau tersebut terus berlanjut sejak proklamasi dan perang kemerdekaan tahun 1945-1949, hingga nasionalisasi perkebunan swasta Belanda di tahun 1958. Masa nasionalisasi merupakan keputusan nasional di tengah kondisi ekonomi dan politik yang tidak menentu. Kondisi ekonomi Indonesia pasca penyerahan kedaulatan tidak sepenuhnya berada dalam kendali pemerintahan Indonesia, sehingga pemerintah tidak bisa mewujudkan ekonomi nasional secepatnya. Dominasi Belanda dalam aset, investasi dan modal sangatlah besar. Hal ini dikarenakan dalam perjanjian KMB, pemerintah Indonesia mempunyai kewajiban untuk melindungi aset, investasi dan modal Belanda dalam kegiatan perusahaan dan usahanya di Indonesia. $^{21}$

Pergolakan dan ketidakstabilan politik yang terjadi ketika masa perang hingga menjelang nasionalisasi membuat beberapa perkebunan menciut dan kehilangan lahan perkebunannya. Pelzer mencatat, pada saat nasionalisasi tahun 1958 hanya tinggal 26 buah perkebunan Tembakau Deli yang beroperasi dengan luas 43.766 ha. Perkebunan Tembakau Deli yang dinasionalisasi dulunya adalah milik Deli Maatschappij dan Senembah Maatschappij. Setelah perkebunan Tembakau Deli dinasionalisasi luas areal penanaman Tembakau Deli mengalami penurunan setiap tahun. Penurunan dan pengurangan lahan perkebunan Tembakau Deli dapat dilihat pada tabel berikut.

${ }^{20}$ Ibid., hlm. 154.

21 Bondan Kanumoyoso, Nasionalisasi Perusahaan Belanda di Indonesia, Jakarta: Pustaka Sinar Harapan, 2001, hal. 18. 
Tabel 3. Daftar Luas Areal Penanaman Tembakau Deli dari 1973-1993

\begin{tabular}{cccccc}
\hline No. & Tahun & Luas Tanaman (ha.) & No. & Tahun & Luas Tanaman (ha.) \\
\hline 1. & 1973 & 4.703 & 12. & 1984 & 3.188 \\
2. & 1974 & 4.554 & 13. & 1985 & 2.800 \\
3. & 1975 & 4.278 & 14. & 1986 & 2.800 \\
4. & 1976 & 4.254 & 15. & 1987 & $2.774,4$ \\
5. & 1977 & 3.629 & 16. & 1988 & $2.725,4$ \\
6. & 1978 & 3.327 & 17. & 1989 & $2.775,4$ \\
7. & 1979 & 3.256 & 18. & 1990 & $2.793,5$ \\
8. & 1980 & 3.031 & 19. & 1991 & $2.796,6$ \\
9. & 1981 & 3.039 & 20. & 1992 & $2.825,4$ \\
10. & 1982 & 3.364 & 21. & 1993 & $2.685,6$ \\
11. & 1983 & 3.017 & & & \\
\hline
\end{tabular}

Sumber: Arsip PTP-IX, PT. Perkebunan-IX (Persero), BPTD; dan Arsip PTP-IX, Konservasi Areal Tembakau PT. Perkebunan-IX (Persero), BPTD.

Dari tabel di atas terlihat pengurangan luas areal penanaman Tembakau Deli selama 20 tahun yakni 1973-1993. Setiap tahun terjadi pengurangan areal penanaman Tembakau Deli secara periodik. Hal ini dilakukan untuk mengantisipasi agar tidak terjadi oversupply yang dapat mengakibatkan penurunan harga jual Tembakau Deli di pasaran dunia. Kebijakan ini dilakukan karena permintaan konsumen terhadap Tembakau Deli mulai terbatas.

Pada tahun 1997, saat mana dikeluarkan Peraturan Daerah Propinsi Daerah Tingkat I Sumatera Utara No. 12 Tahun 1997 tentang Pelestarian Tanaman Tembakau Deli Pada Sebagian Areal HGU PTPN-II Di Propinsi Daerah Tingkat I Sumatera Utara Beserta Petunjuk Penjelasannya, disebutkan hanya terdapat 12 lokasi di kawasan Langkat dan Deli Serdang, perkebunan yang diperuntukkan bagi Tembakau Deli, yakni Kuala Bingai, Kuala Begumit, Tandem Hilir, Tandem, Bulu Cina, Klumpang, Klambir Lima, Helvetia, Saentis, Bandar Klipa, dan Batang Kuis, dengan luas keseluruhan berjumlah 12.816 ha. Namun di tahun 2016 perkebunan yang memproduksi Tembakau Deli hanya ada 3 perkebunan yakni Bulu Cina, Klumpang, dan Helvetia. 


\section{Tembakau Deli : Pemicu Perkembangan Perkebunan Di Sumatera Utara}

Secara historis, harus diakui bahwa Tembakau Deli, adalah komoditas pertama yang dibudidayakan di Sumatera Utara dalam bentuk plantation. Diawali dengan budidaya Tembakau Deli, berbagai komoditas perkebunan lain kemudian dilakukan, seperti karet, teh, dan kelapa sawit. Bahkan, beberapa komoditas juga pernah dibudidayakan oleh perkebunan di Sumatera Utara sejak masa kolonial hingga kemerdekaan. Di masa kolonial, perkebunan juga sempat membudidayakan kopi, gambir, hingga sisal, sedangkan pada masa kemerdekaan kakao juga pernah ditanam. Semua komoditas yang pernah dan masih dibudidayakan di perkebunan yang ada di Sumatera Utara, pemicunya adalah Tembakau Deli.

Keberhasilan budidaya Tembakau Deli yang dipelopori Nienhuijs di tahun 1860-an, serta besarnya permintaan pasar sekaligus harganya yang tinggi, menarik minat investor untuk menanamkan sahamnya di Deli. Sejak itu semakin besar pula permintaan atas lahan di wilayah Sumatera Timur, bahkan melewati batas-batas kekuasaan Kesultanan Deli. Berawal dari Deli sebagai pusatnya, permintaan lahan kemudian meluas hingga ke kawasan Langkat, Serdang, bahkan hingga Asahan dan Bengkalis. Segera setelah tanah konsesi didapat, hutanhutan kemudian dibuka untuk ditanami Tembakau Deli. Kenyataan menunjukkan bahwa banyak onderneming Tembakau Deli yang berada di Utara Langkat, dan bagian Selatan meliputi Serdang, Simalungun, Asahan, hingga Bengkalis mengalami kerugian, karena ternyata tidak berkualitas baik. Hal ini disebabkan oleh kurangnya pengetahuan tentang budidaya, tetapi yang paling penting adalah kenyataan bahwa lahan-lahan tersebut ternyata kurang cocok untuk menghasilkan Tembakau Deli yang berkualitas. Akibatnya, banyak di antaranya ditutup karena mengalami kerugian. Di awal tahun 1890-an penelitian membuktikan bahwa Tembakau Deli memang hanya menghasilkan kualitas terbaik di kawasan antara Sungai Wampu di Langkat, dan Sungai Ular di Deli Serdang.

Antara tahun 1880-an hingga 1910-an, onderneming Tembakau Deli yang merugi kemudian coba beralih ke tanaman lain. Di Serdang misalnya, kopi sempat dibudidayakan, tetapi juga mengalami kerugian. Di Simalungun, sisal juga sempat ditanam. Demikian juga di Asahan, gambir juga sempat dibudidayakan. Lewat serangkaian uji coba, teh kemudian dikembangkan di sekeliling Pematang Siantar antara tahun 1910 hingga tahun 1920. Dalam waktu yang hampir bersamaan, di Tanah Itam Ulu dan Pulau Raja, kelapa sawit juga sudah mulai dibudidayakan di atas lahan eks perkebunan Tembakau Deli. Akan tetapi, yang benarbenar menjadi penyelamat eks onderneming Tembakau Deli, adalah karet. Melalui 
serangkaian uji coba pada periode 1899 hingga 1905, memasuki tahun 1906 karet benarbenar dibudidayakan di banyak lahan eks onderneming Tembakau Deli. Memasuki tahun 1920-an, nilai ekspor karet bahkan sudah mampu menyalib perolehan Tembakau Deli. Perkembangan selanjutnya menunjukkan bahwa perkebunan karet masih terus survive hingga saat ini, kendati mulai tergeser oleh kelapa sawit. Jika diklasifikasikan secara periodik, era kejayaan Perkebunan Tembakau Deli di Sumatera Utara berlangsung sejak 1860-an hingga 1910-an, kejayaan karet berlangsung sejak 1920-an hingga 1980-an, dan sejak tahun 1990-an hingga saat ini primadona perkebunan di Sumatera Utara adalah kelapa sawit. Penjelasan ini tidak berarti bahwa peran perkebunan Tembakau Deli sebagai pemicu perkembangan industri perkebunan menjadi terlupakan. Justeru keberadaan perkebunan saat ini, baik PTPN maupun perkebunan swasta lainnya, harus berterima kasih terhadap Tembakau Deli.

\section{Tembakau Deli: Pemicu Perkembangan Sumatera Utara}

Selain sebagai pemicu perkembangan industri perkebunan, tidak berlebihan pula jika Tembakau Deli layak pula ditempatkan sebagai pemicu dari perkembangan Sumatera Utara. Hal ini cukup beralasan mengingat setelah ekspansi perkebunan Tembakau Deli yang diikuti oleh perkembangan perkebunan komoditas lain, "wajah" Sumatera Utara mengalami perubahan drastis. Dengan tidak bermaksud mengabaikan yang lain, perubahan itu di antaranya adalah terkait dengan jumlah dan komposisi penduduk, pembangunan infrastruktur, serta muncul dan berkembangnya kota.

\section{a. Perubahan Jumlah dan Komposisi Penduduk}

Tembakau Deli merupakan pemicu besarnya jumlah dan komposisi penduduk di Sumatera Utara. Besarnya jumlah dan komposisi penduduk tersebut sengaja dibentuk oleh "perkebunan" yang banyak membutuhkan tenaga kerja untuk sektor perkebunan. Selain itu, faktor lainnya adalah tumbuhnya sektor perekonomian perkebunan sehingga menjadikan magnet bagi para pendatang untuk mencari peruntungan. Besarnya gelombang migrasi merubah jumlah penduduk yang awalnya merupakan daerah "tidak dikenal" menjadi Het Dollar Land.

Angka-angka pertama mengenai jumlah penduduk di Sumatera Timur adalah angkaangka yang berupa taksiran atau perkiraan Anderson ketika melakukan perjalanan ke Sumatera Timur pada tahun 1823. Jumlah penduduk Sumatera Timur berdasarkan perkiraan Anderson adalah sekitar 350.000 jiwa. Angka ini didasarkan pada peendataan yang 
dilakukan Anderson mulai dari Tamiang hingga Siak. ${ }^{22}$ Dari Laporan ini juga dijelaskan bahwa komposisi penduduk di Sumatera Timur terdiri dari berbagai beberapa etnis seperti Melayu dan Karo, sebagai penduduk asli, beberapa koloni Jawa dan para pedagang Cina yang menetap di beberapa kota pelabuhan. Kemudian, 35 tahun berdasarkan pendataan J.S.G Gramberg, kemudian jumlah tersebut berkurang menjadi 150.000 tidak termasuk Tamiang dan Siak.

Tabel 4. Pertumbuhan penduduk kota Medan 1858- 1943

\begin{tabular}{|c|c|c|c|}
\hline No. & Tahun & Jumlah & Sumber \\
\hline 1. & 1858 & 150.000 & J.S.G. Gramberg \\
\hline 2. & 1900 & 420.928 & Deli Data \\
\hline 3. & 1905 & 568.417 & Deli Data \\
\hline 4. & 1915 & 833.320 & Deli Data \\
\hline 5. & 1920 & 1.197 .554 & Deli Data \\
\hline 6. & 1930 & 1.693 .260 & K.J. Pelzer Tabel 21. \\
\hline 7. & 1943 & 1.860 .000 & \\
\hline
\end{tabular}

Tabel di atas menunjukkan bahwa pertumbuhan penduduk mengalami peningkatan yang drastis karena kebutuhan tenaga kerja untuk pengolahan perkebunan tembakau dengan mendatangkan tenaga kerja dari berbagai daerah seperti Semenanjung Malaya dengan tenaga kerja Cina dan India serta wilayah lain seperti Jawa dengan tenaga kerja Jawa, Sunda, Boyan, dan lainnya.

Dari tabel 5 dapat dilihat, golongan pribumi termasuk Melayu, Batak, Jawa, Sunda, Minangkabau dan kelompok-kelompok etnis lainnya di Sumatera Timur. Dari keterangan tersebut, komposisi penduduk Sumatera Timur semakin kompleks karena tidak hanya dari Indonesia, penduduk Sumatera Timur menampakkan wajah internasionalnya dengan adanya penduduk dari Asia dan Eropa.

${ }^{22}$ John Anderson, op.cit., hlm. 209. 
Tabel 5. Pertumbuhan penduduk kota Medan 1858- 1943

\begin{tabular}{ccccc}
\hline Tahun & Eropa & Pribumi & Cina & Arab, India, dll. \\
1900 & 2.097 & 306.035 & 103.768 & 9.028 \\
1905 & 2.667 & 450.941 & 99.236 & 15.573 \\
1915 & 5.200 & 681.800 & 132.000 & 14.320 \\
1920 & 7.882 & 1.042 .930 & 134.750 & 11.992 \\
1930 & 11.079 & 1.470 .395 & 192.822 & 18.904 \\
\hline
\end{tabular}

Sumber: Anthoni Reid, hlm. 110.

Delapan puluh tahun kemudian, yakni pada tahun 1930, jumlah penduduk Sumatera Timur sebanyak 1.693.200 jiwa. Pertumbuhan penduduk ini disebabkan oleh adanya migrasi dalam skala besar para buruh untuk bekerja di perkebunan Sumatera Timur. Pada tahun 1930, sebanyak 301.936 buruh dari Jawa dan Cina telah masuk ke Sumatera Timur. Jumlah seluruh orang Jawa di Sumatera Timur telah mencapai 589.836 atau sekitar $40 \%$ dari seluruh penduduk Sumatera Timur. Ditambah dengan jumlah orang Cina sebanyak 192.822 jiwa, maka lebih dari separuh penduduk Sumatera Timur adalah para pendatang dari luar. ${ }^{23}$

\section{b. Pembangunan Infrastruktur Transportasi}

Transportasi utama sebelum adanya jalan raya dan rel kereta api adalah melalui jalur sungai. Ini dapat ditandai dengan kondisi geografis Sumatera Timur yang banyak dilalui sungai-sungai. Dari sungai hasil-hasil perkebunan yang terletak di pedalaman Sumatera Timur diangkut menggunakan sampan atau kapal berukuran sedang untuk dibawa ke pelabuhan-pelabuhan. Pengangkutan dengan moda sampan sesungguhnya sangat menghambat pihak perkebunan karena muatan yang diangkut jumlahnya sedikit serta memakan waktu yang cukup lama dan biaya yang besar. Hal ini tentu saja tidak efisien bagi pihak perkebunan, sehingga pada akhir abad ke-19 pihak onderneming untuk membangun jalan raya.

Pembangunan jalan raya khususnya di cultuurgebied dipelopori oleh pihak onderneming yang dimaksudkan untuk kepentingan sendiri. Jalan-jalan ini membelah di

${ }^{23}$ Suprayitno. “Medan Sebagai Kota Pembauran Sosio Kultur di Sumatera Utara Pada Masa Kolonial Belanda”. Dalam Historisme No. 21. Agustus 2005, hlm. 5. 
tengah-tengah suatu perkebunan untuk memudahkan penanaman dan pengangkutan hasil panen. Salah satu pihak onderneming yang membangun jalan raya sendiri adalah Deli Maatschappij, pada tahun 1880-an telah membangun jalan antara Medan dan Sunggal sepanjang $10 \mathrm{KM}$ dan dari Lubuk Pakam ke Bangun Purba sepanjang 20 KM. jalan-jalan yang dibangun merupakan jalan untuk menghubungkan perkebunan Tembakau Deli dengan perkebunan Tembakau Deli lainnya.

Pembangunan jalan raya kemudian diteruskan oleh pemerintah, sampai tahun 1918 , pemerintah sudah membangun jalan utama sepanjang lebih dari 500 KM yang menghubungkan kota-kota penting di cultuurgebied. Jalur-jalur yang dibuka adalah Medan ke Pangkalan Berandan melewati Binjai dan Tanjung Pura dibangun jalan sepanjang 107 KM, Medan ke Tebing Tinggi sepanjang $81 \mathrm{KM}$, kemudian dilanjutkan dari Tebing Tinggi ke Tanjung Balai dan terus ke perbatasan Kualuh di Asahan sepanjang 115 KM, Medan ke Belawan 22 KM, Medan ke Kabanjahe sepanjang 79 KM, Lubuk Pakam di Serdang ke Seribu Dolok di Simalungun dibangun jalan sepanjang 92 KM, Tebing Tinggi ke Pematang Siantar 53 KM, Pematang Siantar ke Parapat 46, 5 KM, serta Kabanjahe melewati Seribu Dolok di Simalungun ke Danau Toba. Selain itu jalan penghubung cultuurgebied dengan daerah lain juga dibangun, seperti dari Kabanjahe ke Kotacane, serta dari Parapat ke Tapanuli. $^{24}$

Kemajuan dan perkembangan transportasi membuat orang terus menerus berusaha mencari cara bagaimana menyelenggarakan transportasi yang cepat dan lancar. Pemerintah akhirnya mengembangkan transportasi rel yang mampu meringankan beban dalam daya dorongannya sehingga mampu mengangkut hasil-hasil perkebunan yang lebih banyak. Adanya kebijakan ini sehingga perusahaan kereta api segera melibatkan dirinya dalam membangun sarana transportasi di wilayah perkebunan. ${ }^{25}$

Wilayah Sumatera Timur terkenal setelah pemerintah menetapkan wilayah ini sebagai kantung-kantung perkebunan yang kemudian diekspor ke Eropah maupun ke Amerika. Kereta api berperan dalam transportasi baik dari daerah pedalaman perkebunan hingga barang-barang dapat ditempatkan di pelabuhan-pelabuhan untuk segera diangkut melalui kapal laut.

\footnotetext{
${ }^{24}$ R. Broersma, Oostkust van Sumatra: De Ontwikkeling van het Gewest, deel II, The Hague: Charles Dixon Deventer, 1922, hlm. 263.

25 Indera, "Pertumbuhan dan Perkembangan Deli Spoorweg Maatschappij, 1883-1940" Tesis S-2, belum diterbitkan, Depok: Universitas Indonesia, 1996, hlm. 52.
} 
Kebijakan ini merupakan jawaban atas kebutuhan pihak perkebunan terhadap transportasi. Jaringan kereta api yang dibangun pada akhir abad ke 19 bertujuan untuk melayani ekonomi ekspor dan impor kolonial yang tumbuh pesat. ${ }^{26}$ Realisasi pembangunan jaringan rel kereta api di Sumatera Timur, pada awalnya difokuskan di tiga daerah yang meliputi daerah Deli, Serdang dan Selesei. Daerah-daerah ini sangat memungkinkan untuk dibangun jaringan rel kereta api karena kondisi tanah yang datar dan dekat dengan Kota Medan. $^{27}$

Selama 37 tahun yakni mulai dari tahun 1886 hingga 1937, Deli Spoorweg Maatschappij (DSM) telah membangun jaringan rel kereta api sepanjang 553,254 KM. Daerah-daerah yang dibangun meliputi Medan ke Labuhan sepanjang 16,743 KM yang dibangun pada tahun 1886, Medan ke Binjai Sepanjang 20,888 KM yang dibangun pada tahun 1887, Medan ke Deli Tua sepanjang 11,249 KM yang dibangun pada tahun 1887, Labuhan ke Belawan sepanjang 6,162 KM yang dibangun pada tahun 1888, Medan ke Serdang sepanjang 20,122 KM yang dibangun pada tahun 1889, Serdang ke Perbaungan sepanjang 17,668 KM yang dibangun pada tahun 1890, Binjai ke Selesei sepanjang 10,576 yang dibangun pada tahun 1890, Stabat ke Binjai sepanjang 22,428 KM, Stabat ke Tanjung Pura sepanjang 14,036 KM, Tanjung Pura ke Pangkalan Berandan sepanjang 19,505 KM yang ketiga jalur ini dibangun pada tahun 1900, Selesei ke Kuala sepanjang 9,943 KM yang dibangun pada tahun 1902, Bamban ke Perbaungan sepanjang 30,350 KM yang dibangun pada tahun 1902, Bamban ke Rantau Laban sepanjang 10,680 KM yang dibangun pada tahun 1903, Lubuk Pakam ke Bangun Purba sepanjang 27,936 KM yang dibangun pada tahun 1904, Kampung Baru ke Arnhemia (Pancur Batu) sepanjang 14,872 KM yang dibangun pada tahun 1907, Deli Tua ke Batu sepanjang 3,035 KM yang dibangun pada tahun 1915, Rantau Laban ke Tanjung Balai sepanjang 95,062 KM yang dibangun pada tahun 1915, Tebing Tinggi ke Pematang Siantar sepanjang 48,464 KM yang dibangun pada tahun 1916, Tanjung Balai ke Teluk Nibung sepanjang 5,132 KM yang dibangun pada tahun 1918, Pangkalan Berandan ke Besitang sepanjang 14,990 KM yang dibangun pada tahun 1919, Besitang ke Pangkalan Susu sepanjang 9,510 KM yang dibangun pada tahun 1921, Kisaran ke Membang Muda sepanjang

\footnotetext{
${ }^{26}$ Ibid., hlm. 53.

${ }^{27}$ Ibid., hlm. 90.
} 
57,111 Km yang dibangun pada tahun 1926 dan Milano ke Rantau Prapat sepanjang 12,562 Km yang dibangun pada tahun $1937 .^{28}$

Pembangunan jalur rel kereta api ini memberi dampak yang positif bagi perkembangan ekonomi di perkebunan. Dampak positif ini dapat dilihat dengan volume daya angkut yang banyak sehingga tidak berkali-kali mengangkut hasil panen perkebunan yang banyak menghabiskan biaya operasional. Selain bagi perkebunan, pembangunan rel kereta api juga memberi dampak positif bagi Pelabuhan Tanjung Balai Asahan dimana perkebunanperkebunan yang berada di wilayah Asahan dengan mudah mengirim hasil panen ke pelabuhan yang kemudian di ekspor. Akibat yang diperoleh dengan keuntungan besar karena perusahaan ini memiliki hak monopoli angkutan perkebunan.

\section{c. Muncul dan Berkembangnya Kota}

Tembakau Deli juga memiliki andil dalam perkembangan daerah. Kota-kota baru, terutama Medan, juga terbangun atas andil Tembakau Deli. Bahkan Kota Medan hingga kini menjadi kota terbesar ketiga di Indonesia setelah Jakarta dan Surabaya, dan menjadi kota terbesar di luar Pulau Jawa. Hal yang sama juga berlaku atas kota-kota lain, seperti Tanjung Pura, Binjai, dan Lubuk Pakam. Dikarenakan Tembakau Deli juga memicu pertumbuhan perkebunan karet, kelapa sawit, dan teh, tidak berlebihan pula jika dikatakan bahwa Tembakau Deli berperan atas terbentuknya kota-kota lain di eks-Keresidenan Sumatera Timur, seperti Tebing Tinggi, Pematang Siantar, Kisaran, Tanjung Balai, dan Rantau Prapat. Ini belum termasuk kota-kota kecil lainnya, sperti Pancur Batu, Tanjung Morawa, Galang, Dolok Masihul, Indra Pura, Perdagangan, Lima Puluh, dan lain-lain.

Sebelum adanya perkebunan kota-kota seperti Binjai, Tanjung Pura, Lubuk Pakam, Perbaungan, Pematang Siantar bahkan Medan sekalipun hanyalah sebuah perkampungan yang dihuni oleh beberapa ribu penduduk saja. Setelah kehadiran perkebunan khususnya Tembakau Deli, merubah wajah perkampungan menjadi kota yang ramai. Hal ini dapat terjadi karena banyak kota-kota baru muncul karena kebetulan wilayah tersebut dilintasi oleh jalur perhubungan darat seperti jalan raya dan rel kereta api.

Pengembangan Kota Medan mulai berjalan sejak Jacobus Nienhuys pindah ke kampung Medan tahun 1869, seiring dengan berkembangnya industri perkebunan tembakau. Pertumbuhan ekonomi dari suatu perlombaan penanaman modal rupanya membutuhkan suatu

\footnotetext{
${ }^{28}$ Ibid., hlm. 90-110.
} 
kawasan pusat administrasi seperti halnya kota-kota di Eropa. Menjelang akhir abad ke-19, kampung Medan berangsur-angsur diperluas ke arah hulu sungai Deli dan Babura, sementara pusat kota ditetapkan di dekat areal makam Panglima Perungit di pinggir sungai Deli. De Deli Mij berpartisipasi dengan menyerahkan lahan seluas 225 ha dari konsesi perkebunan Mabar-Delitua dan 63 ha dari kebun Polonia untuk lahan kota baru, tentunya atas seizin Sultan Deli. ${ }^{29}$ Demikianlah Kota Medan berkembang pesat sebagai simbol perkebunan. Pada awal paruh pertama abad ke-20, laju pertumbuhan ekonomi di Medan meningkat sangat pesat sebagai akibat diversifikasi tanaman perkebunan, meskipun tembakau tetap menjadi komoditas andalan. Tidak hanya Medan, kota-kota lainnya di Sumatera Timur juga mengalami hal serupa ketika banyak perusahaan-perusahaan menempatkan kantor perusahaannya di kota-kota lain seperti Kisaran, Rantauparapat, Tanjung Morawa, Binjai, dan lainnya.

\section{SIMPULAN}

Dari uraian di atas, dapat dikatakan bahwa Tembakau Deli memiliki nilai historis yang tinggi. Tembakau Deli adalah bagian dari sejarah masa lalu Bangsa Indonesia, khususnya Sumatera Utara. Ia adalah pemicu bagi perkembangan industri perkebunan, dan lebih dari itu ia juga adalah pemicu bagi perkembangan Sumatera Utara. Tembakau Deli adalah khas Sumatera Utara, dan karenanya ia adalah salah satu ikon penting bagi Sumatera Utara. Pentingnya Tembakau Deli sebagai kebanggaan dapat ditunjukkan dengan pencantumannya paling tidak pada enam logo di daerah Sumatera Utara, yakni logo Provinsi Sumatera Utara, Kota Medan, Kabupaten Deli Serdang, Universitas Sumatera Utara, PSMS Medan, dan PSDS Deli Serdang.

Berdasarkan arti pentingnya Tembakau Deli dari perspektif historis itu, maka sudah selayaknyalah ia dilestarikan dan dilindungi. Menurut UU RI Nomor 11 Tahun 2010 Tentang Cagar Budaya yang dimaksud dengan Pelestarian adalah upaya dinamis untuk mempertahankan keberadaan Cagar Budaya dan nilainya dengan cara melindungi, mengembangkan, dan memanfaatkannya. Sementara itu, menurut UU yang sama Perlindungan adalah upaya mencegah dan menanggulangi dari kerusakan, kehancuran, atau kemusnahan dengan cara Penyelamatan, Pengamanan, Zonasi, Pemeliharaan, dan Pemugaran Cagar Budaya.

${ }^{29}$ Tengku Luckman Sinar. Sejarah Medan Tempo Doeloe. Medan: Perwira. 2001, hlm. 44. 
Tembakau Deli, sesuai dengan UU RI Nomor 11 Tahun 2010 Tentang Cagar Budaya, layak diklasifikasikan sebagai Benda Cagar Budaya, sesuai dengan bunyi Pasal 1 ayat 2 yang menyatakan bahwa, "Benda Cagar Budaya adalah benda alam dan/atau benda buatan manusia, baik bergerak maupun tidak bergerak, berupa kesatuan atau kelompok, atau bagian-bagiannya, atau sisa-sisanya yang memiliki hubungan erat dengan kebudayaan dan sejarah perkembangan manusia." Selain itu, sebelum terlambat, Perkebunan Tembakau Deli yang masih tersisa di PTPN 2 menurut UU yang sama, sangat layak dijadikan Situs Cagar Budaya. Pasal 1 ayat 5 menyebutkan, bahwa "Situs Cagar Budaya adalah lokasi yang berada di darat dan/atau di air yang mengandung Benda Cagar Budaya, Bangunan Cagar Budaya, dan/atau Struktur Cagar Budaya sebagai hasil kegiatan manusia atau bukti kejadian masa lalu".

Berdasarkan Undang-Undang tersebut, kiranya rencana untuk memberhentikan/menghapus budidaya Tembakau Deli di lingkungan PTPN 2 Tanjung Morawa perlu lebih dipertimbangkan lagi. Secara ekonomis, Tembakau Deli mungkin sudah kurang berarti. Akan tetapi, dari sisi sejarah dan juga kebudayaan, Tembakau Deli berikut Perkebunan Tembakau Deli perlu untuk dilestarikan dan dilindungi, sebelum mengalami kepunahan.

\section{DAFTAR PUSTAKA}

Anderson, John. Mission to the East Coast of Sumatra in 1823. New York: Oxford University. 1971.

Baron de Raet, J.A.M. van Cats. "Vergelijking van de vroegeren Toestand van Deli, Serdang, en Langkat", dalam Tijdschrift voor Indische Taal, Land, en Volkenkunde van Bataviasch Genootschap, deel XII, 1887.

Breman, Jan. Menjinakkan Sang Kuli: Politik Kolonial, Tuan Kebun, dan Kuli di Sumatera Timur pada Awal Abad ke-20. Jakarta: Pustaka Utama Grafiti dan KITLV. 1997.

Broersma, R. Oostkust van Sumatra: De Ontwikkeling van het Gewest, deel II, The Hague: Charles Dixon Deventer. 1922.

Fatimah, "Pengaruh Sosial Ekonomis Perkebunan Tembakau Terhadap Masyarakat di Sumatera Timur" Tesis belum diterbitkan. Yogyakarta: Universitas Gadjah Mada. 1985.

Indera, "Pertumbuhan dan Perkembangan Deli Spoorweg Maatschappij 1883-1940" Tesis S2, belum diterbitkan. Depok: Universitas Indonesia. 1996.

Kanumoyoso, Bondan. Nasionalisasi Perusahaan Belanda di Indonesia. Jakarta: Pustaka Sinar Harapan. 2001.

Pelzer, Karl J. Toean Keboen dan Petani: Politik Kolonial dan Perjuangan Agraria. Jakarta: Pustaka Sinar Harapan. 1985. 
Said, Mohammad. Koeli Kontrak Tempoe Doeloe: dengan Derita dan Kemarahannya. Medan: Waspada. 1977.

Sinar, Tengku Luckman. Sejarah Medan Tempo Doeloe. Medan: Perwira. 2001.

Stoler, Ann Laura. Kapitalisme dan Konfrontasi di Sabuk Perkebunan Sumatera (18701979). Yogyakarta: Karsa. 2005.

Sumarno, Edi. "Mundurnya Kota Pelabuhan Tradisional di Sumatera Timur pada Periode Kolonial" dalam Historisme Edisi NO.22/Tahun XI/Agustus 2006.

Suprayitno. "Medan Sebagai Kota Pembauran Sosio Kultur di Sumatera Utara Pada Masa Kolonial Belanda". Dalam Historisme No. 21. Agustus 2005.

Volker, T. Van Oerbosch Tot Cultuurgebied: Een Schets van de Beteekenis van de Tabak, de Andere Cultures, en de Industrie ter Oostkust van Sumatra. Medan: De Deli Planters Vereeniging. 1918.

Wie, Thee Kian. Plantation Agriculture and Export Growth an Economic History of East Sumatra 1863-1942. Jakarta: National of Institute of Economic and Social Research (LEKNAS - LIPI). 1977. 